\title{
EFFECT OF INTEGRATION OF GREEN CONSTRUCTS AND TRADITIONAL CONSTRUCTS OF BRAND ON GREEN PURCHASE INTENTION OF CUSTOMERS
}

\author{
Ahmad Esmaeili, Akbar Sepahvand, Reza Rostamzadeh, \\ Izolda Joksiene, Jurgita Antucheviciene
}

\section{Introduction}

Most recently, a number of customers have shown concern over the considerable damage caused to the environment. Natural resources are gradually being replete, and climate change threats are the most important of these concerns (Euro barometer, 2011; European Commission, 2010; Lapinskienè et al., 2015; Barrier, 2016). Formerly, organizations avoided investing in support of the environment, which became a setback for their own future progress (Chen, 2010). Presently, as a result of increased attention to the environment, they tend to take greater responsibility for the environment than before (Chang \& Chieng, 2006). Even the studies highlight the role of future generations as being vital toward eco-awareness (Simionescu, 2013; Csigéné Nagypál et al., 2015). One of the main actions that the companies have taken in this regard is green marketing, known as environmental marketing or social marketing, which refers to a kind of attitude of social marketing with all the ethical, social, environmental, and human values put in processes, tools, and marketing and sales behavior in order to achieve stability in business. This has resulted in increase in the number of marketing studies on environmental issues, and the influence of activities of the companies shows the importance of green marketing (Chamorro et al., 2009; Lee, 2008; Zhu et al., 2016; Suki, 2017). Since green products are becoming increasingly popular, more and more customers prefer to buy green products (Royne et al., 2011; De Angelis et al., 2017; Li et al. 2016). Furthermore, the companies' pioneering innovations let them be the 'first one', thus allowing them to charge higher prices for their green products (price skimming), improve their organizational image, develop their markets and enjoy rivalry benefits (Hart, 1995; Peattie, 1995). However, the challenge facing companies is to remove their customers' doubt regarding the proper quality and function of the green products, and whether these products carry the features of being green or not (Kalafatis et al., 1999; Aagerup et al., 2016). In recent years, the companies have claimed a lot to be producing green products, but only later it turned out that such claims were nothing but frauds, this becoming a serious challenge for the companies (Chen \& Chang, 2012; Kalafatis et al., 1999). This shows that the companies are facing two main issues in green marketing, one of them being the proper function of a product and the other one - the issue of production of a product which is environmentally friendly ( $\mathrm{Ng}$ et al., 2014). As for the second issue, which is how to create a positive attitude towards environmentally friendly products, we have seen new constructs, such as green image, green trust, green satisfaction, and the equity of a green brand, all of which have attempted to create a positive attitude towards the green brand (Chen, 2010; Chen \& Chang, 2012). However, these green marketing constructs present us with only a general understanding of customers and cannot justify the customers' purchase behavior when buying green products (Rios et al., 2006; Mourad et al., 2012). Respectively, in order to respond to the needs of customers the companies must pay close attention to green marketing, since it takes human beings' health into consideration and prevents harm to the environment. Thus, many companies 
see this as an opportunity and want to make the best out of it (Rahman \& Haque, 2011). In developing countries, this is a major concern due to the fact that environmental regulations are insufficient. However, the companies tend to be more environmentally concerned and, in some cases, some remarkable actions have taken place. Companies are suggested to rely on marketing communication strategies, rather than just green advertising strategies (Bailey et al., 2016). These communication strategies appeal to customers green consumption values which are embedded within customers' minds.

The next level of analysis is the everincreasing importance of green marketing and its role in the success of companies, which is necessary to investigate various dimensions of green marketing and to find their relationship with traditional variables. Many studies have investigated the relationship between traditional branding constructs (such as the quality of a product brand, the credibility of the brand, the equity of the brand), yet few studies have considered the relationship between green branding constructs (Chen, 2010; Chen \& Chang, 2013). Furthermore, few researchers had investigated the relationship between traditional constructs and green branding as a whole framework before $\mathrm{Ng}$ et al. (2014). Therefore, in our suggested model we have combined the two elements of the perceived quality and credibility of a brand that can influence customers' trust regarding both of the above problems with green marketing constructs. This research can serve as validation of the constructs to fill the literature gap in the investigation of green brand dimensions. Thus, the aim of this research is to examine the mutual impact of traditional branding constructs (perceived brand quality and brand credibility) and the constructs of green branding (green brand perceived value and green brand image), brand equity and subsequently its impact on the green purchase intention of the customer. Secondly, this study aims at examining an inferential model, including both green and traditional branding constructs, as the green features of products, if taken on their own, are not of importance. It is the impact of traditional constructs on special green value and green purchase intention that is the focus of this research.

In this research, along with the model proposed by $\mathrm{Ng}$ et al. (2014), the researchers first investigate the mutual impact of traditional branding constructs (perceived brand quality and brand credibility) and green branding constructs (green brand image, green brand perceived value, and green brand equity). Since previous research has not investigated the impact of customers' green brand equity, we will investigate the mutual impact of traditional constructs and green constructs as well as green brand equity and the customers' green purchase intention.

The rest of the paper is structured as follows. In Section 1, a literature review is presented and hypotheses of the paper regarding different dimensions of the proposed model are considered. Section 2 discusses the methodology of the research, and Section 3 puts forward findings of the present research. An analysis of data and hypothesis tests, model analysis, and hypothesis testing are included in Section 3. Finally, the implications of the study alongside with discussion of the results are presented in the first part of Section 4. In addition, the managerial implications of the paper for an improved understanding of the concepts and findings of the research are provided in the second part of Section 4.

\section{Review of Conceptual and Experimental Literature}

There has been a substantial change in the attitude of society regarding environmental awareness. More and more customers are willing to buy green products with the least negative impact on the environment (Peattie, 1995). Companies are not an exception and have initiated a green marketing strategy to secure themselves with regard to environmental regulations, to respond to customer demand, to offer green products and to create competitive advantage in the market (Grant, 2008; Bekk et al., 2015; Chen et al., 2016). This trend needs a change in the philosophy of manufacturing and marketing (Polonsky \& Rosenberger, 2001). Roe et al. (2001) have proposed that responding to a consumer's green need could alter the future of manufacturing capacity in the USA in terms of renewable generation of products. The change in the philosophy of manufacturing has been analyzed in terms of the green purchase behavior of consumers within the framework of the Theory of Reasoned Action (TRA) (Pickett-Baker \& Ozaki, 2008; Gupta \& Ogden, 2009; Kalafatis et al., 1999; 
Paul et al., 2016). The TRA suggests that the consumers' purchase intention is deeply influenced by subjective attitudes of the consumers as regards environmental issues. An extensive discussion on the TRA has voiced support for the prediction of the consumers' intentions or the behavior of the consumers (Mostafa, 2007; Cheah, 2009; Nadlifatin et al., 2016).

Moreover, by developing a green marketing strategy companies gain a competitive advantage (Porter and van der Linde, 1995; Chen et al., 2006; Wang, 2016). Chen and Chan (2012) have proposed a model to analyze the effect of green perceived value and green perceived risk on the green purchase intention of consumers in order to examine the benefits gained by the companies. These authors have introduced green trust as a mediator in the model and confirmed the positive impact of green perceived value on green trust and green purchase intention. At the same time, green perceived risk can negatively affect the above-mentioned constructs. The authors argue that the increase in green perceived value and the decrease in green perceived risk may increase green trust and green purchase intention. Huang et al. (2014) argue that with the increase in green brand knowledge, a positive attitude towards a green brand is created among consumers and green purchase intention increases accordingly. Furthermore, research results indicate a difference among the consumers. Those with a commitment to environmental issues are more likely to buy green products, while those being less concerned focus on price (Gilg et al., 2005; Maniatis, 2016).

Since its emergence in the late 1990s, the term brand equity has become one of the most important marketing concepts both in research and practice (Srinivasan et al., 2005). With focus on environmental business and consumer research, Chen (2010) introduced the construct of green brand equity. Brand equity has been defined as the intangible part of a brand name, inherently within the brand name (Mohd Yasin et al., 2007). Brand equity could be seen from two perspectives: the financial value that it creates for firms (Simon \& Sullivan, 1993) and the value created for consumers (Keller, 1993; Aaker, 1991). Former studies have thoroughly investigated brand equity as a general concept in marketing and there exists little studies in field of green marketing. Bekk et al. (2015) point out that there are only four models proposed on the green brand equity concept. Moreover, the literature on brand equity includes a broader set of meanings and attributes in favor of the customer relationship (Yoo et al., 2000). Four constructs have been investigated by Chen (2010) to analyze the effect of three drivers, namely green brand image, green satisfaction, and green trust, on green brand equity. The positive relationship between these three constructs on green brand equity has been confirmed. Kang et al. (2012) have suggested five constructs for green brand equity, that is, green satisfaction, green affect, green trust, green brand loyalty, and green brand equity. They have analyzed the effect of these constructs on green brand equity. The results indicate that there exists a positive relationship between green brand loyalty and green brand equity. They also propose that green impact characterized by a positive emotional commitment could set grounds for green loyalty and green brand equity. Perceived green quality, green brand awareness, and green perceived risk have also been analyzed by Chen \& Chang (2013) to explore relationships among them. The results indicate a positive and significant relationship between, on the one hand, perceived green quality and green brand awareness and, on the other hand, green brand equity. Furthermore, perceived green quality can negatively affect perceived green risk, which in its own turn can negatively influence green brand awareness and green brand equity. $\mathrm{Ng}$ et al. (2014) have analyzed the effect of perceived brand quality and brand credibility on consumers' perception of green brand value, green brand image, and green brand equity. These authors have concluded that perceived brand quality and the overall credibility of a brand have a positive impact on the creation of green image, green perceived value, and equity.

\section{Developing a Theoretical Model (Hypotheses) \\ 2.1 Positive Effect of Perceived Brand Quality on Green Brand Image}

Brand quality, as perceived by customers, has been defined in various ways. Aaker (1991) defines it as the quality or preference that a product creates in the mind of the customer 
in comparison to other products in the market. In fact, perceived quality is not the real quality of the product, rather it is an evaluation of the product in the mind of the customer (Erenkol et al., 2010). Perceived quality is an advantage that makes a brand famous and affects brand image in a positive way (Jarvinen \& Suomi, 2011). A brand with the advantage of good perceived quality for the customer can create a positive image in the mind of the customer, which affects the attitude of the customer towards the brand, causes the customer's loyalty and repurchase intention (Arslan \& Altuna, 2010).

The brand image is the features which customers assign to the brand in their mind (Aaker, 1996). Many studies have been conducted regarding the impact of perceived brand quality on brand image, however it is $\mathrm{Ng}$ et al. (2014) who first established that green perceived brand quality has a positive influence on green brand image. Chen (2010) defines the green brand image as the customer's perception of the extent to which the brand is concerned about the environment and is positively active in environmental activities. Accordingly, the first hypothesis has been formulated as follows:

$H_{1}$ : Perceived brand quality have a positive effect on green brand image.

\subsection{Positive Effect of Perceived Quality on Green Brand Value}

According to Aaker (1996), a brand's value can be measured in two dimensions: (a) whether the brand provides good value for money, (b) whether there are reasons to buy this brand rather than that of competitors. Further research on the subject suggests that there is a difference between a brand's value and the perceived brand quality. Perceived brand quality is associated with the respect which the brand holds, while the value of the brand is a functional dimension and the practical benefit of a certain brand (Aaker, 1996). This means that the two concepts can be regarded as separate, but their relationship may be important. Sweeney et al. (1999) define the perceived brand quality in relation to its price. The perceived brand quality can increase in two ways; through the special quality of a product or through the increase of the price of the goods or services which are purchased (Parasuraman \& Grewal, 2000). In market terms, Chen \& Chang (2012) define green perceived value as the general evaluation of sheer benefit in exchange for buying a green product based on environmental interests, expectations, and needs of the consumer. In green marketing, the green attractions of a brand are combined with traditional values in a unified way to convince the customer to make a purchase. Therefore, it is not surprising that green products can influence customers to make purchases, an intention in which traditional aspects are combined and create values accordingly. At the beginning of green marketing, researchers observed some negligence in paying attention to traditional aspects of goods and products, which determined a lower rate of the customers' purchases of green products due to their low quality. In addition, companies' efforts to create high-quality green products have constantly disfigured the mentality of customers with regards to the function and quality of the green products. This has caused some brands to put higher prices on products because of the mentality of better quality (Ottman et al., 2006). Various researchers conclude that the enhancement of perceived value of a brand can offer a higher quality (Jahanzeb et al., 2013). Therefore, we can assume that Perceived brand quality can have an impressive impact on the evaluation of environmentally friendly products, hence our third hypothesis will be:

$\mathrm{H}_{2}$ : Perceived quality of a brand is positively affected by green brand value.

\subsection{Positive Effect of Perceived Brand Quality on the Brand Credibility}

Brands are well-known signs (that is, believable and trustworthy) and show honesty of a company (Erdem et al., 2002). According to this definition, the brand credibility is based on two main categories: (1) trustworthiness (that is, a company tends to do as it promises) and, (2) expertise (that is, the belief that the company can do as it promises) (Sweeney \& Swait, 2008). To the best end, attribution theory links the service quality to corporate credibility. This theory suggests that when someone faces a difficulty in understanding a situation, he/she tends to finds the way out by assigning a cause to the situation which gives him/her a greater control of life and surrounding environment (Folkes, 1988). Later, researchers argue that the corporate credibility of a brand has the potential to be attributed to concepts like customer perceived value and service quality (Zeithaml, 2000). 
With regards to new products in the market (such as environmentally friendly products), a better quality of manufactured products is necessary to keep and reinforce their credibility among customers (Sternthal et al., 1978; Del Rio et al., 2016). Therefore, our next hypothesis is:

$H_{3}:$ The perceived quality of a brand has a positive effect on the credibility of the brand.

\subsection{Positive Effect of Brand Credibility on the Brand Perceived Value}

Since it plays a strategic role in marketing behavior, credibility is considered to be an important element in the success of communications and has been the focus of attention of scientific circles (Flavián et al., 2005). The effect of green attractions may be alleviated by brand equity, and brand equity may, in turn, affect the brand perceived value by customers and alter the customer's intention to select the brand (Hauser \& Wernerfelt, 1990). According to the theory of properly brand perceived value, perceived value is another term for the perceived appropriateness of a brand, which is concerned with the risk and price based on which the customers decide what they need and what they acquire (Snoj et al., 2004). The brand credibility reduces perceived risk, because it increases the claims of the customers about the products of a company. Credibility also decreases communication expenses, since consumers use well-known brands as a source of information in order to reduce the expenses related to search for, collection, and processing of information (Erdem \& Swait, 2004; Giannarakis et al., 2016). When the perceived risk of the brand decreases, the brand's value increases (Snoj et al., 2004). In their paper, $\mathrm{Ng}$ et al. (2014) mention the positive effect of a brand's credibility on the perceived value of a green brand, hence our fourth hypothesis:

$H_{4}$ : The credibility of a brand has a positive impact on green brand value.

\subsection{Positive Effect of Brand Credibility on Green Brand Image}

In order to be able to create the image of being environmentally friendly in the mind of customers, first the brand credibility has to be achieved ( $\mathrm{Ng}$ et al., 2014). The brand credibility of an organization's is a key element in the customers' purchasing intention and is essential in creating an image for the organization (Lafferty et al., 2002). Cooperation with environmentally friendly organizations can increase the green brand credibility. This is probably due to the fact that when a company cooperates with an environmentally friendly organization, for the customer being environmentally friendly makes more sense (Mendelson \& Polonsky, 1995). When a wellknown brand manufactures environmentally friendly products, it strengthens its credibility and removes the doubts and distrust of the customers towards the environmental issues of the company and makes it believable. Therefore, we can conclude that the credibility of a brand influences green brand image ( $\mathrm{Ng}$ et al., 2014). Hence our fifth hypothesis:

$H_{5}$ : Credibility of a brand has a positive influence on green brand image.

\subsection{Positive Effect of Brand Credibility on Green Brand Equity}

One of the most important and most famous concepts in marketing which is the topic of extensive discussions among researchers is the equity of a brand. Its importance is determined by its leading and impressive role in making managerial intentions and creating rivalry and competitive settings (Atilgan et al., 2005). Aaker (1991) defines four characteristics of brand value: knowing about the brand, perceived quality, brand associations, brand loyalty, and other features of the brand (rights, etc). Mohd Yasin et al. (2007) define brand equity as a collection of brand properties on the commitments and environmental concerns related to a brand that improves the value provided by a product or service. In this regard, the value of the brand includes financial possessions and other related issues. It can be called the value that is added to a product or what a customer perceives as the value of the product. The first one to define green equity was Chen (2010), based on the definitions proposed be Aaker (1991), Chen (2010) puts it this way: "a set of all the possessions and debts of a brand, in relation to the green commitments, and the environmental issues which are related to the name of the brand, symbol, and logo, and can increase or decrease the value of a brand in the mind of the customer, through creating environmentally friendly products". The most important advantage of a special brand for a company is that it enables the organization to find for itself a new different status. 
Previous studies show that the brand credibility, through fame in comparison to other less-known competitors in the market, can help a company in business (Aaker \& Joachimsthaler, 2000). Papasolomou and Vrontis (2006) claim that companies with more valid brands have a stronger brand equity. According to Erdem and Swait (1998), the brand credibility is like a central pillar for any company which wants to achieve equity and management. $\mathrm{Ng}$ et al. (2014) say that the new concept of green equity, as a subcategory of brand equity, can be influenced by brand credibility. Thus, our sixth hypothesis would be:

$H_{6}$ : Brand credibility has a positive influence on brand equity.

\subsection{Positive Influence of a Green Brand's Perceived Value on Green Brand Equity}

Previous studies show that customers believe that consumption of environmentally friendly goods is more beneficial than that of traditional products (Hartmann \& Apaolaza-lbáñez, 2012). Therefore, a strong and positive value perceived by customers in respect of a brand is important because of the positive effect it has (Malik, 2012). Studies show that, in relation to perceived quality, perceived value can predict the satisfaction of customers (Cronin et al., 2000). When the perceived value of a customer in relation to green products is higher, the customer is more determined to purchase a product (Chen \& Chang, 2012). In other words, when traditional attractions of green products are more appropriate they function as a complement in creating perceived value for the customer, which encourages the customer to purchase the brand (Hartmann \& ApaolazaIbáñez, 2012). There exist a positive effect between green brand perceived value and green brand equity ( $\mathrm{Ng}$ et al., 2014). Hence our seventh hypothesis:

$H_{7}: A$ green brand perceived value has a positive influence on green brand equity.

\subsection{Positive Effect of Green Brand Image on Green Brand Equity}

The image of a brand includes symbolic meanings which are related to special features of the brand and can be related to the products which a company has. This is also called the mental image of a brand in the mind of the customer (Cretu \& Brodie, 2007). Based on previous definitions, Chen (2010) defines a green brand as "a set of beliefs, worries, and imaginations in the mind of the customer which is related to the maintenance and caring for the environment". The customers' attitude towards the brand has a positive influence on the customers' trust and can reduce perceived risk and increase the possibility of making a purchase while doing business (Chen, 2010). When the brand is able to recreate the image of being green or regard for the environment in the mind of the customer, that brand has a successful and agreeable image (Chen, 2008). The positive effect of brand image on brand equity in previous studies has been shown and proved (Aaker, 1991; Keller, 1993). In a new study, some positive relationship of green brand image has been found. Moreover, Biel (1992) claims that brand image drives brand equity, according to which the enhancement of brand image will enhance brand equity (Faircloth et al., 2001). Chen (2010) reported the positive effect of green brand image on green brand equity. Therefore, our eighth hypothesis is as follows:

$H_{8}$ : Green brand image has a positive effect on green brand equity.

\subsection{Positive Effect of Brand Equity on Green Purchase Intention}

Ajzen (1991) claims that if a customer has strong intention toward buying a product, purchase intention will transcend to actual purchase. Thus it would be likely for a customer to buy a green product if he/she has great intention to do so. In this regard, Keller (2013) highlights the importance of purchase intention during the evaluation phase of a certain product by customers. Also, purchase intention can be used to predict purchasing process of customers (Ghosh, 1990). In other words, customers are driven by purchase intention and later on they decide whether to buy or not. Most scholars consider research on elements of a brand with green purchase intention to be essential and state the need for even more research in this field (Chen, 2010; Rios et al., 2006). The purchase intention of customers is investigated by asking questions, such as "the level of thinking while buying" or "the probability of purchase" or "wanting to buy" (Zeithaml, 1988). Green purchase intention is defined as the customers' level of real purchase in relation 
to environmentally friendly products or brands whose green attractions they know about (Oliver \& Lee, 2010). Many studies related to the effect of the brand's equity on the customers' purchase intention have shown their interrelationship (Chen \& Chang, 2008; Senthilnathan \& Tharmi, 2012). Conscience knowledge has been highlighted as being at the core of acquisition of a product or service, which is to be deliberate and with an eye on consequences (Follows \& Jobber, 2000). Therefore, since a green brand's equity and green purchase intention are part of brand equity and purchase intention, our ninth hypothesis will be:

$H_{g}$ : Special green brand value has a positive effect on green brand purchase intention.

According to the literature review in different fields of traditional and green marketing and based on $\mathrm{Ng}$ et al. (2014), we have proposed our theoretical framework in Fig. 1.

\section{Fig. 1: Conceptual model of the research}

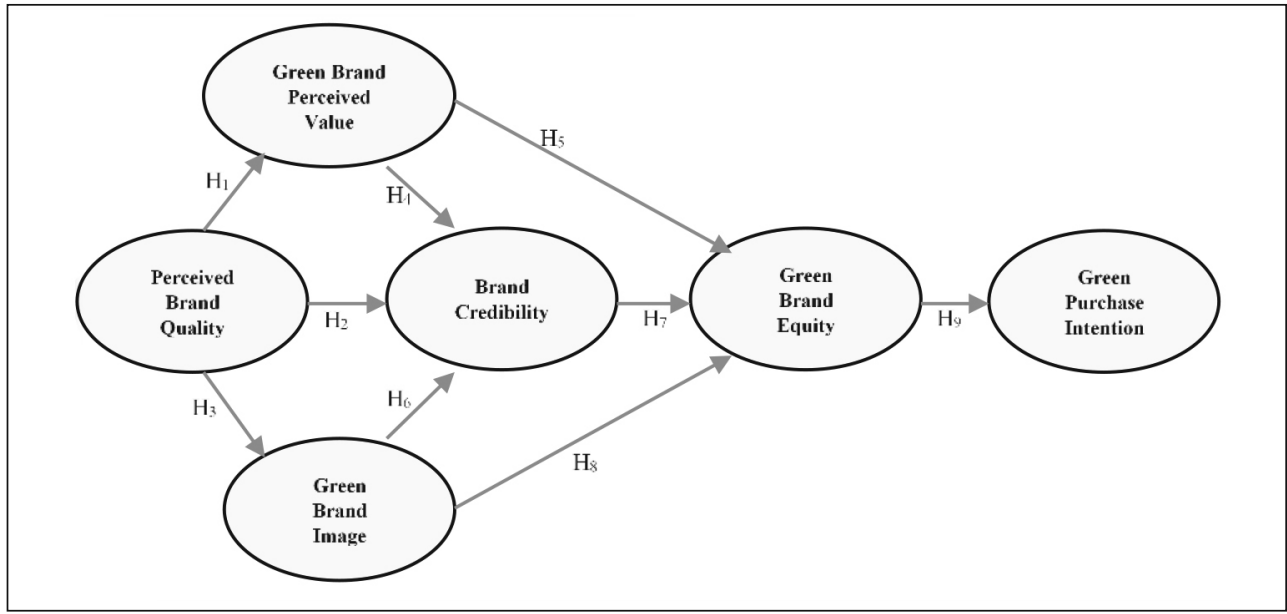

Source: own

\section{Methodology of the Research}

In terms of the aim of the research, the present study is functional, while in terms of data collection it is descriptive. For the experimental analysis, 26 items have been employed to evaluate different variables. In order to investigate the relationship between the variables and to examine the hypotheses, the LISREL 7 software has been used. The research participants are consumers of certain products who have bought the products of a company at least once. The clustering method has been chosen for data collection. After dividing the city of Tehran into five regions, the questionnaires were filled out by the customers. Using Cochran's method, the sample size was estimated to be 384 people. For the purposes of categorization of the sample, Tehran was first divided into five categories (north, south, east, west and center), and the questionnaires were filled out by the customers inside supermarkets in these geographic areas. All the respondents were contacted face to face at various times during the week. Owing to the novelty of the concepts and the constructs, the reliability of the questions has been evaluated by the experts in marketing and has been finalized with some corrections. To examine the reliability of a questionnaire, the first set of 30 questionnaires was examined and, using the data and by means of Cronbach's Alpha, inserted in the SPSS 21 software. According to Tab. 1 , the reliability of the questionnaires was tested for all the variables and was more than $70 \%$, which is an acceptable rate for the reliability of the questionnaire. 
Tab. 1: Items corresponding to variables and calculated reliability of the questionnaire

\begin{tabular}{|c|c|c|c|}
\hline Variables & Items & Source & $\begin{array}{c}\text { Cronbach's } \\
\text { Alpha }\end{array}$ \\
\hline $\begin{array}{l}\text { Perceived } \\
\text { brand quality }\end{array}$ & $\begin{array}{l}\text { - The brand is of high quality. } \\
\text { - The likely quality of this brand is extremely high. } \\
\text { very high. } \\
\text { - The likelihood that this brand is reliable is very high. } \\
\text { - This brand must be of very good quality }\end{array}$ & $\begin{array}{l}\text { Washburn \& } \\
\text { Plank (2002) }\end{array}$ & 0.806 \\
\hline $\begin{array}{l}\text { Brand } \\
\text { credibility }\end{array}$ & $\begin{array}{l}\text { - My favorite brand delivers what it promises. } \\
\text { - } \begin{array}{l}\text { The service claims from my favorite brand are } \\
\text { Over time, my experiences with my favorite brand } \\
\text { have led me to expect it to keep its promises, no } \\
\text { more and no less. } \\
\text { - My favorite brand is committed to delivering on its } \\
\text { claim, no more and no less. } \\
\text { - My favorite brand has a name I can trust. } \\
\text { My favorite brand has the ability to deliver what it } \\
\text { promises. }\end{array}\end{array}$ & $\begin{array}{l}\text { Newell \& } \\
\text { Goldsmith } \\
(2001)\end{array}$ & 0.861 \\
\hline $\begin{array}{l}\text { Green brand } \\
\text { image }\end{array}$ & $\begin{array}{l}\text { - The brand is regarded as the best benchmark of } \\
\text { environmental commitments. } \\
\text { - The brand is professional about environmental } \\
\text { reputation. } \\
\text { - The brand is well established about the } \\
\text { environmental concern. } \\
\text { - The brand is trustworthy about environmental } \\
\text { promises. }\end{array}$ & Chen (2010) & 0.837 \\
\hline $\begin{array}{l}\text { Green brand } \\
\text { perceived } \\
\text { value }\end{array}$ & $\begin{array}{l}\text { - This brand's environmental function provides very } \\
\text { good value for me. } \\
\text { - This brand's environmental performance meets my } \\
\text { expectations. } \\
\text { I purchase this brand because it is environmentally } \\
\text { friendly. } \\
\text { I purchase this brand because it has, an } \\
\text { environmental benefit than other products. }\end{array}$ & $\begin{array}{c}\text { Chen \& } \\
\text { Chang (2012) }\end{array}$ & 0.747 \\
\hline $\begin{array}{l}\text { Green brand } \\
\text { equity }\end{array}$ & $\begin{array}{l}\text { - It makes sense to buy this brand instead of other } \\
\text { brands because of its environmental commitments, } \\
\text { even if they are the same. } \\
\text { Even if another brand has the same environmental } \\
\text { features as this brand, I would prefer to buy this } \\
\text { brand } \\
\text { - If there is another brand's environmental } \\
\text { performance as well as this brand, I prefer to buy } \\
\text { this brand } \\
\text { If the environmental concern of another brand is not } \\
\text { different from that of this brand in any way, it seems } \\
\text { smarter to purchase this brand }\end{array}$ & $\begin{array}{c}\text { Chen \& } \\
\text { Chang (2012) }\end{array}$ & 0.821 \\
\hline $\begin{array}{l}\text { Green } \\
\text { purchase } \\
\text { intention }\end{array}$ & $\begin{array}{l}\text { - The likelihood that I will purchase the next product of } \\
\text { this green product } \\
\text { - I would buy the product out of concern for the } \\
\text { environment } \\
\text { - The possibility of my purchasing the product is high }\end{array}$ & $\begin{array}{l}\text { Huang et al. } \\
\text { (2014) }\end{array}$ & 0.705 \\
\hline
\end{tabular}




\section{Tab. 2: Descriptive statistics}

\begin{tabular}{l|l|c|c}
\multicolumn{1}{c|}{ Variable } & \multicolumn{1}{|c|}{ Range } & Frequency & Percent \\
\hline \multirow{4}{*}{ Age } & $20-30$ & 183 & $47.5 \%$ \\
\cline { 2 - 4 } & $31-40$ & 96 & $25 \%$ \\
\cline { 2 - 4 } & $41-50$ & 67 & $17.5 \%$ \\
\cline { 2 - 4 } & $51-u p$ & 38 & $10 \%$ \\
\hline \multirow{2}{*}{ Eex } & Male & 211 & $54 \%$ \\
\cline { 2 - 4 } & Female & 173 & $46 \%$ \\
\hline \multirow{2}{*}{ Education } & Diploma or lower degree & 77 & $20 \%$ \\
\cline { 2 - 4 } & Associate degree & 194 & $51 \%$ \\
\cline { 2 - 4 } & Master's degree or higher & 113 & $29 \%$ \\
\hline
\end{tabular}

Source: own

\section{Research Findings}

\subsection{Descriptive Statistics}

In order to better know the participants of the study and the variables, they should be defined before analyzing these statistical data. Demographics are shown in Tab. 2.

\subsection{Correlation between Variables}

The analysis of the hypotheses of the study is based on a covariance matrix between hidden variables and apparent variables. Tab. 3 shows the covariance matrix (correlation) between the hidden variables. According to the findings, almost all the variables of the study are $99 \%$ significant. In order to examine the normality of the distribution, one sample Kolmogorov-Smirnov test has been performed. If the $p$-value is bigger than 0.05 , the null hypothesis (the normality of the distribution) is confirmed, and if the $p$-value is smaller or equal to 0.05 , the alternative hypothesis (abnormality of the distribution) is confirmed. The findings indicate that, for all the variables, the null hypothesis is confirmed at $95 \%$ level of confidence.

\subsection{Model Analysis}

In order to examine the hypotheses and understand relationships between elements of the model, LISERL 7 has been employed. The findings of the analysis of the model for equation coefficients of the variables or, in other terms, of the path analysis are shown in Fig. 2.

To investigate the significance of path coefficients, the T-value needs to be calculated. Fig. 3 represents estimated T-values for the variables.

\section{Tab. 3: Correlation between variables}

\begin{tabular}{l|c|c|c|c|c|c}
\multicolumn{1}{c|}{ Variables } & $\mathbf{1}$ & $\mathbf{2}$ & $\mathbf{3}$ & $\mathbf{4}$ & $\mathbf{5}$ & $\mathbf{6}$ \\
\hline Perceived brand quality & 1 & & & & & \\
\hline Brand Credibility & 0.62 & 1 & & & & \\
\hline Green Brand Image & 0.67 & 0.56 & 1 & & & \\
\hline Green Brand Perceived Value & 0.61 & 0.65 & 0.67 & 1 & & \\
\hline Green Brand Equity & 0.59 & 0.68 & 0.57 & 0.52 & 1 & \\
\hline Green Purchase Intention & 0.56 & 0.67 & 0.48 & 0.57 & 0.72 & 1 \\
\hline Mean & 3.14 & 2.98 & 3.32 & 3.03 & 3.02 & 2.91 \\
\hline Average Variance & 0.91 & 0.94 & 0.86 & 0.86 & 0.99 & 0.93 \\
\hline
\end{tabular}




\subsection{Goodness of Fit Tests}

Various research papers have utilized different goodness of fit tests. In order to validate a model, researchers normally use three to five indices. To test the goodness of fit in this research, the authors have made use of some renowned indices whose values are represented in Tab. 4. GFI, AGFI, RMSEA, NFI, $\mathrm{NNFI}$ and $\mathrm{CFI}$ are among these indices.

The purpose of evaluation of the goodness of fit indices is to investigate the idea that to what extent the model is compatible with the collected data. From the above-mentioned indices, none has priority over another. Based on the sample size, estimation method, the complexity of the model and the normal distribution of the collected data, different indices can be utilized and interpreted. As shown in Tab. 4, the calculated values are NFI $=0.95, \mathrm{NNFI}=0.931$, $\mathrm{CFI}=0.97, \mathrm{X}^{2}$ with the degree of freedom of 2.563 and RMSEA $=0.086$, which represents the model as having an acceptable goodness of fit index.

\section{Fig. 2: Determination of $R^{2}$ coefficient and path coefficients of variables}

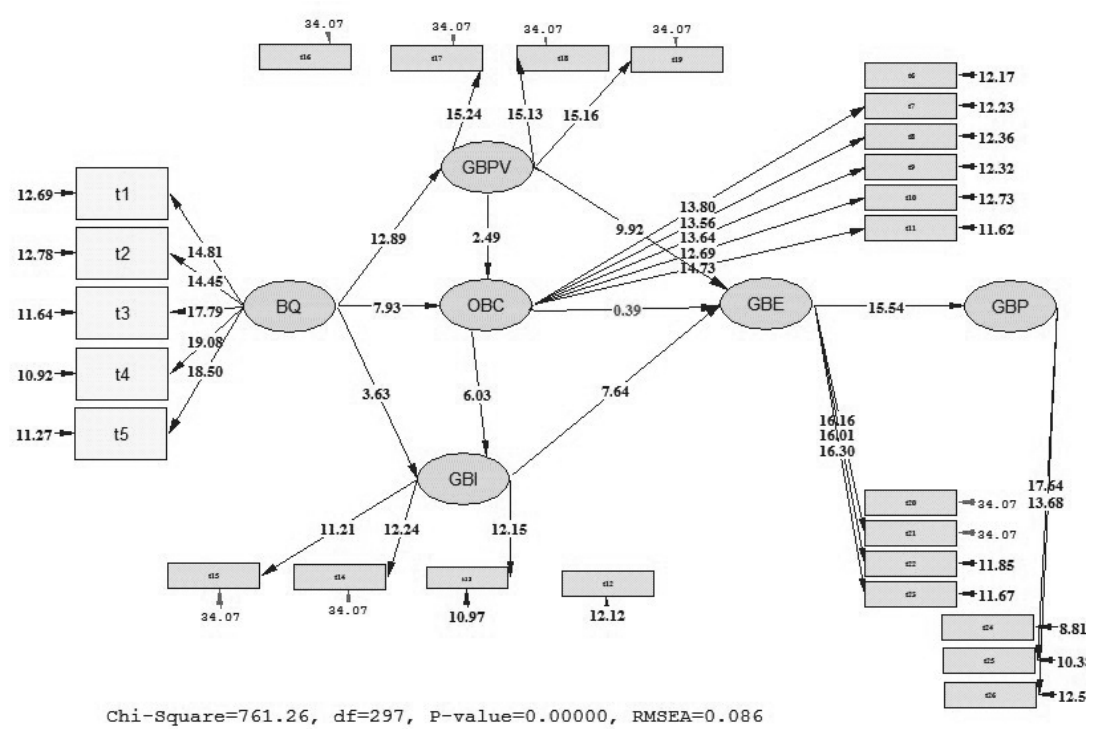

Source: own

\subsection{Hypothesis Testing}

As the model has been approved, it can be used to test the hypotheses of the study. Tab. 5 shows the findings regarding the relationship between each of the variables of the study.

The results of this research suggest that perceived brand quality has a significant and positive influence on the Green brand perceive value $(H 1)$, overall Brand credibility $(H 2)$, and Green brand image (H3). Similarly, the Green perceived value significantly influences Brand credibility (H4) and Green brand equity (H5). Also, brand credibility has a positive influence on the Green brand image ( $\mathrm{H} 6)$ but fails to have any significant direct effect on Green brand equity ( $\mathrm{H} 7)$. Furthermore, Green brand image significantly influences green brand equity (H8). Finally, the research findings suggest that green brand equity has a significant and positive influence on green purchase intention (H9). 


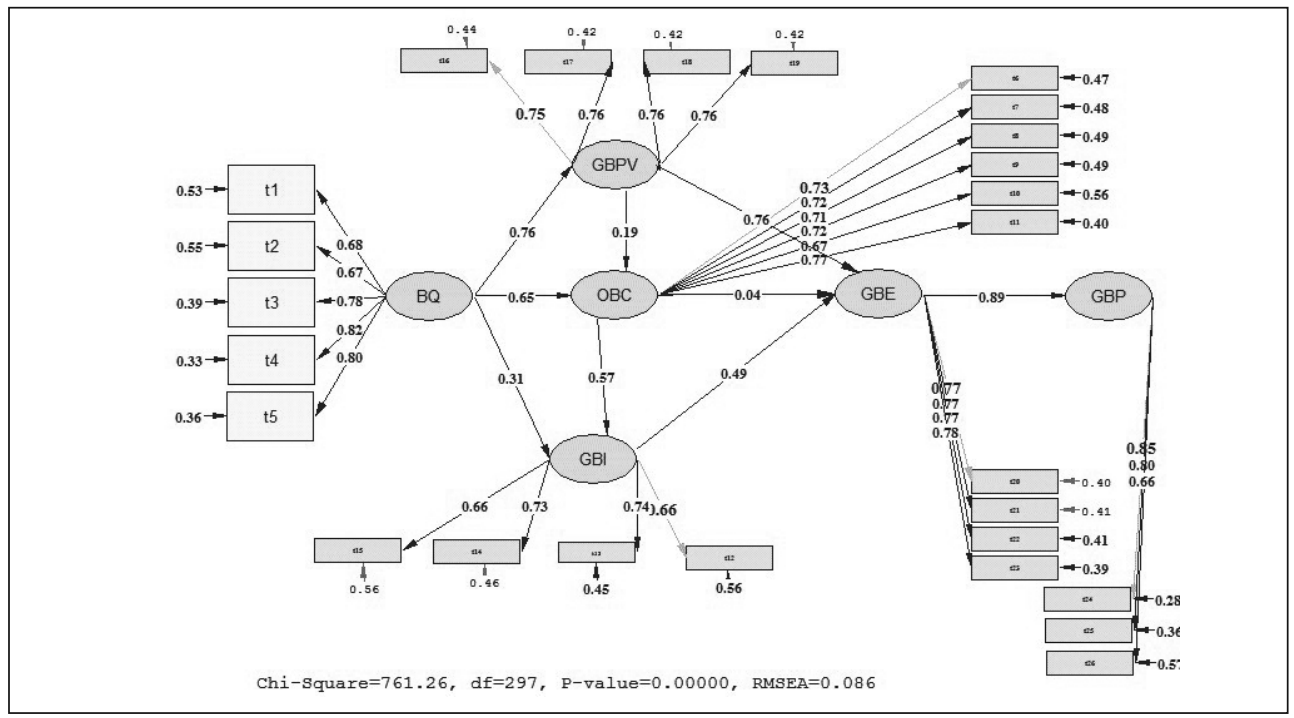

Source: own

Tab. 4:

Goodness of fit tests

\begin{tabular}{l|c|c}
\multicolumn{1}{c|}{ Index } & Value of index & Accepted rate \\
\hline$X^{2} / d_{f}$ & 2.563 & Between 1 to 3 \\
\hline Goodness of Fit Index (GFI) & 0.810 & GFI > 90\% \\
\hline Adjusted Goodness of Fit Index (AGFI) & 0.780 & AGFI > 90\% \\
\hline Root Mean Square Error of Approximation (RMSEA) & 0.086 & RMSEA < 10\% \\
\hline Normed Fit Index (NFI) & 0.950 & $\mathrm{NFI} \mathrm{>} \mathrm{90 \%}$ \\
\hline NNFI (Non-Normed Fit Index) & 0.960 & $\mathrm{NNFI} \mathrm{>90 \%}$ \\
\hline CFI (Comparative Fit Index) & 0.970 & $\mathrm{CFI}>90 \%$ \\
\hline
\end{tabular}

Source: own

\section{Discussion}

The majority of consumers are increasingly changing their views on green products and green image of companies, which is also accelerated by the global awareness of the environment. The consumers are willing to pay for eco-friendly products and to adjust their habits in order to protect the environment (Kang et al., 2012; Chamorro \& Bañegil, 2006). Thus, it has become a necessity for firms to combine green philosophy with traditional concepts of production and marketing. The contribution of this research can be best summarized as follows:

- A literature review is presented to enhance the concepts and to provide a better understanding of the marketing constructs concerning the green concept;

- Traditional constructs are presented alongside with new constructs;

- A practical model is presented to test hypotheses and to set a basis for further studies. 


\section{Tab. 5: Hypothesis testing}

\begin{tabular}{c|l|r|r|l}
\multicolumn{2}{c|}{ Hypothesis } & T-Value & $\begin{array}{c}\text { Path- } \\
\text {-Coefficient }\end{array}$ & $\begin{array}{c}\text { Supported } \\
\text { or Not } \\
\text { Supported }\end{array}$ \\
\hline 1 & Perceived brand quality $\rightarrow$ Green brand perceive value & 12.89 & 0.76 & supported \\
\hline 2 & Perceived brand quality $\rightarrow$ Brand credibility & 7.93 & 0.65 & supported \\
\hline 3 & Perceived brand quality $\rightarrow$ Green brand image & 3.63 & 0.36 & supported \\
\hline 4 & Green Brand Perceived Value $\rightarrow$ Brand credibility & 2.49 & 0.19 & supported \\
\hline 5 & Green Brand Perceived Value $\rightarrow$ Green brand equity & 9.92 & 0.76 & supported \\
\hline 6 & Brand Credibility $\rightarrow$ Green brand image & 6.03 & 0.57 & supported \\
\hline 7 & Brand Credibility $\rightarrow$ Green brand equity & 0.39 & 0.04 & not supported \\
\hline 8 & Green Brand Image $\rightarrow$ Green brand equity & 7.64 & 0.49 & supported \\
\hline 9 & Green Brand Equity $\rightarrow$ Green purchase intention & 15.54 & 0.89 & supported \\
\hline
\end{tabular}

Source: own

Moreover, in order to develop such a model with due regard to the literature on brand and brand making the researchers have decided to formulate nine hypotheses in the form of a conceptual model. The findings have been fitted, and the effect of the perceived quality of customers of a brand on elements of a green brand's perceived value, the credibility of the brand and green brand image and the effect of green perceived value and green brand image on green brand equity have been shown. The results indicate the conformity of the analysis to $\mathrm{Ng}$ et al. (2014) in terms of positive effect of green brand image on green brand equity and to Bekk et al. (2015) which associates higher green brand image to green brand equity. In addition, the effect of green brand equity on the customers' purchase intention has been evaluated positively. Faircloth et al. (2001) also indicate that there is a positive relationship between green brand image and green brand equity, which is mediated by the satisfaction and trust of the customers. Furthermore, the credibility of the brand does not have any effect on brand equity, which is found in the works of $\mathrm{Ng}$ et al. (2014). These findings are almost in line with those of $\mathrm{Ng}$ et al. (2014), although in his work there is no direct relationship between perceived quality and green perceived value, while in our study, we observe a great deal of the effect of perceived quality on green perceived value. The rest of the findings also support the views presented in the works of $\mathrm{Ng}$ et al. (2014).

One should keep in mind that according to Aaker (1992), in order to take proactive decisions managers of brand equity must know that how the value attributed to brand equity is created. The findings of this study show that neglecting traditional concepts of marketing for companies with an interest in green marketing can incur them a lot of unwanted expense. A company that pays attention only to the environmental aspects of marketing and ignores the traditional elements of marketing, the credibility of a brand and perceived quality will certainly face many troubles (Mourad et al., 2012). The companies must consider both cases at the same time. Another result of this study is that we have observed an effect of two elements of perceived quality and the credibility of the brand on green brand image (hypotheses 3 and 6). The two elements have an impressive effect on green brand image, which shows that the traditional elements have an important effect on green brand image, and the companies can use them as a lever to enhance green brand image and to affect green brand equity. One of the main concerns regarding green brand equity could be enhanced by the focus of the companies on 
merging green brand image, green satisfaction, and green trust into concepts and taking them into account as the main dimensions of the strategic planning phase of brand development (Chen, 2010).

This study has attempted to fill the research gap in terms of the relationship between green brand constructs and traditional branding constructs. This can be best described as a mission for the management to pursue environmentally green practices, both securing market advantages and sustainability throughout the market.

\section{Conclusions}

Considering the importance of the phenomenon in question for the environment, nowadays many companies have focused their attention on this phenomenon and, by making use of it, have turned it into an opportunity. A number of companies have missed this opportunity and have tried to gain more customers through false claims of being environmentally friendly, which means that a well-known and trustworthy brand for the customers is becoming a necessity. However, it is not enough merely to become an environmentally friendly brand, because as it has already been said, customers have their doubts about the function of these companies. Therefore, the companies must be aware of the quality of the products which are referred to as environmentally friendly. In fact, the companies should build an image which both identifies green and also the high quality of a product. Hence, in this study we have decided to employ a model that applies both traditional aspects (perceived quality and credibility) and green aspects of a brand (green brand image and the perceived value of a green brand, special green brand) of products and considers the effect of these functions on the green purchase intention of customers. The promotion of goods and services all around the world is bound to green brand image which is the underlying constituent of green brand equity. Thus, this study justifies the importance of green concepts as a marketing tool to adjust and influence green brand equity of the products. This study argues that quality is not an isolated concept, but rather thoroughly linked to marketing construct to generate positive attitudes toward brands. A firm must not only focus on delivering high quality products and services, but also to justify the eco-friendly dimensions of the activities, products, and services to gain a higher rate of perceived value. To do this, firms must take significant steps forward to build positive quality perception among customers. This involves greenness beside good quality. The perception of quality is as equally important as products or services. The positive effect of perception of quality on marketing performance has been proved numerously (Sweeney et al., 1999). It shoud be noted that firms, must pay attention on how to build green brand image, green brand value and perceived green quality at the same time. The promotion of green lifestyle can be cnsidered as a way to associate the products or services with customers and grasp a simultaneous value for the firms. This provides firms with larger market shares and a power to sell at higher prices with higher profit margins (Jung \& Sung, 2008). Researchers have distinguished a critical period in brand analysis during economic crisis (Grundey, 2009). The analysis provided in this research can be improved if tested during economic downturns, which has shown a different behavior in terms of customers' perception toward brands and it also can be further extended to the green brands during a time that only price counts.

On the other hand, we have faced a lack of literary sources that would fit all of these features in a single model, thus we have developed a model encompassing these features in order to fill in this gap.

In this study, by combining green and traditional constructs in Iran we have concluded for the first time that they affect each other as well as special green brand value. Another innovation of this study has been identification of the positive effect of green brand equity on green purchase intention, with no track in previous studies.

Certainly, this study has its own limitations, one of which being the fact that we have examined only the industry which is recommended for future studies as a multiindustry. Another limitation of this study is related to its variables. In future studies, it is advised to investigate other brand state with the attitude towards the brand.

\section{References}

Aagerup, U., \& Nilsson, J. (2016). Green Consumer Behavior: Being Good or Seeming Good? Journal of Product 
and Brand Management, 25(3), 274-284. doi:10.1108/jpbm-06-2015-0903.

Aaker, D. A. (1991). Managing brand equity. New York: The Free Press.

Aaker, D. A. (1992). The Value of Brand Equity. Journal of Business Strategy, 13(4), 27-32. doi:10.1108/eb039503.

Aaker, D. A. (1996). Measuring Brand Equity Across Products and Markets. California Management Review, 38(3), 102-120. doi:10.2307/41165845.

Aaker, D. A., \& Joachimsthaler, E. (2000). Brand leadership. New York: The Free Press.

Ajzen, I. (1991). The theory of planned behavior. Organizational Behavior and Human Decision Processes, 50(2), 179-211. doi:10.1016/0749-5978(91)90020-T.

Arslan, F. M., \& Altuna, O. K. (2010). The Effect of Brand Extensions on Product Brand Image. Journal of Product \& Brand Management, 19(3), 170-180. doi:10.1108/10610421011046157.

Atilgan, E., Aksoy, S., \& Akinci, S. (2005). Determinants of the Brand Equity: A Verification Approach in the Beverage Industry in Turkey. Marketing Intelligence \& Planning, 23(3), 237-248. doi:10.1108/02634500510597283.

Bailey, A. A., Mishra, A., \& Tiamiyu, M. F. (2016). GREEN consumption values and Indian consumers' response to marketing communications. Journal of Consumer Marketing, 33(7), 562-573. doi:10.1108/JCM-12-2015-1632.

Barrier, E. B. (2016). Building the Green Economy. Canadian Public Policy-Analyse de Politiques, 42(1), Suppl. 1, S1-S9. doi:10.3138/cpp.2015-017.

Bekk, M., Spoerrle, M., \& Hedjasie, R., \& Kerschreiter, R. (2015). Greening the Competitive Advantage: Antecedents and Consequences of Green Brand Equity. Quality \& Quantity, 50(4), 1727-1746. doi:10.1007/s11135-015-0232-y.

Biel, A. L. (1992). How Brand Image Drives Brand Equity. Journal of Advertising Research, 32(6), 6-12.

Chamorro, A., \& Bañegil, T. M. (2006). Green Marketing Philosophy: A Study of Spanish Firms with Ecolabels. Corporate Social Responsibility and Environmental Management, 13(1), 11-24. doi:10.1002/csr.83.

Chamorro, R., Rubio, S., \& Miranda, F. J. (2009). Characteristics of Research on Green Marketing. Business Strategy and the Environment, 18(4), 223-239. doi:10.1002/bse.571.
Chang, P., \& Chieng, M. (2006). Building Consumer-Brand Relationship: A CrossCultural Experience View. Psychology \& Marketing, 23(11), 927-959. doi:10.1002/ mar.20140.

Cheah, C. M. (2009). A study consumers' green purchasing intention (Doctoral dissertation). University Utara, Malaysia.

Chen, C. F., \& Chang, Y. Y. (2008). Airline Brand Equity, Brand Preference and Purchase Intentions: The Moderating Effects of Switching Costs. Journal of Air TransportManagement, 14(1), 40-42. doi:10.1016/j.jairtraman.2007.11.003.

Chen, M.-Y., \& Chiu, Ch.-I. (2016). Go Green: How to Influence the Perceived Effectiveness of a Green Product? International Journal of Advertising, 35(4), 622-641. doi:10.1080/02650487.2015.1105647.

Chen, Y. S. (2008). The Driver of Green Innovation and Green Image-Green Core Competence. Journal of Business Ethics, 81(3), 531-543. doi:10.1007/s10551-007-9522-1.

Chen, Y. S. (2010). The Drivers of Green Brand Equity: Green Brand Image, Green Satisfaction, and Green Trust. Journal of Business Ethics, 93(2), 307-319. doi:10.1007/s10551-009-0223-9.

Chen, Y. S., \& Chang, C. (2013). Greenwash and Green Trust: The Mediation Effects of Green Consumer Confusion and Green Perceived Risk. Journal of Business Ethics, 114(3), 489500. doi:10.1007/s10551-012-1360-0.

Chen, Y. S., \& Chang, C. H. (2012). Enhance Green Purchase Intentions: The Roles of Green Perceived Value, Green Perceived Risk, and Green Trust. Management Decision, 50(3), 502-520. doi:10.1108/00251741211216250.

Chen, Y. S., Lai, S. B., \& Wen, C. T. (2006). The Influence of Green Innovation Performance on the Corporate Advantage in Taiwan. Journal of Business Ethics, 67(4), 331-339. doi:10.1007/ s10551-006-9025-5.

Cretu, A. E., \& Brodie, R. J. (2007). The Influence of Brand Image and Company Reputation Where Manufacturers Market to Small Firms: A Customer Value Perspective. Industrial Marketing Management, 36(2), 230-240. doi:10.1016/j.indmarman.2005.08.013.

Cronin, J. J., Brady, M. K., \& Hult, G. T. M. (2000). Assessing the Effects of Quality, Value, and Customer Satisfaction on Consumer Behavioral Intentions in Service Environments. Journal of Retailing, 76(2), 193-218. doi:10.1016/S0022-4359(00)00028-2. 
Csigéné Nagypál, N., Görög, G., Harazin, P., \& Péterné Baranyi, R. (2015). „Future Generations" and Sustainable Consumption. Economics and Sociology, 8(4), 207-224. doi:10.14254/2071-789X.2015/8-4/15.

De Angelis, M., Acligtizel, F., \& Amatulli, C. (2017). The Role of Design Similarity in Consumers' Evaluation of New Green Products: An Investigation of Luxury Fashion Brands. Journal of Cleaner Production, 141, 1515-1527. doi:10.1016/j.jclepro.2016.09.230.

Del Rio, P., Carrillo-Hermosilla, J., Konnola, T., \& Bleda, M. (2016). Resources, Capabilities and Competences for Eco-Innovation. Technological and Economic Development of Economy, 22(2), 274-292. doi:10.3846/202949 13.2015.1070301.

Erdem, T., \& Swait, J. (1998). Brand Equity as a Signalling Phenomenon. Journal of Consumer Psychology, 7(2), 131-157. doi:10.1207/s15327663jcp0702_02.

Erdem, T., \& Swait, J. (2004). Brand Credibility, Brand Consideration, and Choice. Journal of Consumer Research, 31(1), 191-198. doi:10.1086/383434.

Erdem, T., Swait, J., \& Louviere, J. (2002). The Impact of Brand Credibility on Consumer Price Sensitivity. International Journal of Research in Marketing, 19(1), 1-19. doi:10.1016/S0167-8116(01)00048-9.

Erenkol, H., Anıl, D., \& Duygun, A. (2010). Customers' Perceived Brand Equity and a Research on the Customers of Bellona: Which is a Turkish Furniture Brand. The Journal of American Academy of Business, 16(1), 93-109.

Eurobarometer. (2011). Attitudes of European citizens towards the environment: Special Eurobarometer 36. Retrieved October 15, 2016, from http://ec.europa.eu/environment/ pdf/EB_summar.

European Commission. (2010). Europe 2020. A strategy for smart, sustainable and inclusive growth. Retrieved October 15, 2016, from http://eur-lex.europa.eu/LexUriServ/Lex UriServ.do?uri=COM:2010:2020:FIN:EN:PDF.

Faircloth, J. B., Capella, L. M., \& Alford, B. L. (2001). The Effect of Brand Attitude and Brand Image on Brand Equity. Journal of Marketing Theory and Practice, 9(3), 61-75. doi:10.1080 /10696679.2001.11501897.

Flavián, C., Guinaliu, M., \& Torres, E. (2005). The Influence of Corporate Image on Consumer Trust: A Comparative Analysis in Traditional Versus Internet
Banking. Internet Research, 15(4), 447-470. doi:10.1108/10662240510615191.

Folkes, V. S. (1988). Recent attribution research in consumer behavior: a review and new directions. Journal of Consumer Research, 14(4), 548-565. doi:10.1086/209135.

Follows, S., \& Jobber, D. (2000). Environmentally Responsible Purchase Behaviour: A Test of Consumer Model. European Journal of Marketing, 34(5/6), 723-746. doi:10.1108/03090560010322009.

Ghosh, A. (1990). Retail Management (2nd ed.). Chicago, IL: The Dryden Press.

Giannarakis, G., Zafeiriou, R., Sariannidis, N., \& Efthalitsidou, K. (2016). Determinants of Dissemination of Environmental Information: An Empirical Survey. Journal of Business Economics and Management, 17(5), 749-764. doi:10.3846/16111699.2016.1195771.

Gilg, A., Barr, S., \& Ford, N. (2005). Green Consumption or Sustainable Lifestyles? Identifying the Sustainable Consumer. Futures, 37(6), 481-504. doi:10.1016/j.futures.2004.10.016.

Grant, J. (2008). Green Marketing. Strategic Direction, 24(6), 25-27. doi:10.1108/02580540810868041.

Grundey, D. (2009). Branding Strategies during Economic Crisis: Avoiding the Erosion. Economics and Sociology, 2(2), 9-22. doi:10.14254/2071-789X.2009/2-2/1.

Gupta, S., \& Ogden, D. T. (2009). To Buy or not to Buy? A Social Dilemma Perspective on Green Buying. Journal of Consumer Marketing, 26(6), 376-391. doi:10.1108/07363760910988201.

Hart, S. L. (1995). A Natural-ResourceBased View of the Firm. Academy of Management Review, 20, 986-1014.

Hartmann, P., \& Apaolaza-lbáñez, V. (2012). Consumer Attitude and Purchase Intention Toward Green Energy Brands: The Roles of Psychological Benefits and Environmental Concern. Journal of Business Research, 65(9), 1254-1263. doi:10.1016/j.jbusres.2011.11.001.

Hauser, J. R., \& Wernerfelt, B. (1990). An Evaluation Cost Model of Consideration Sets. Journal of Consumer Research, 16(4), 393-408. doi:10.1086/209225.

Huang, Y. C., Yang, M., \& Wang, Y. C. (2014). Effects of the Green brand on Green Purchase Intention. Marketing Intelligence \& Planning, 32(3), 250-268. doi:10.1108/MIP-102012-0105. 
Jahanzeb, S., Fatima, T., \& Butt, M. M. (2013). How Service Quality Influences Brand Equity: The Dual Mediating Role of Perceived Value and Corporate Credibility. International Journal of Bank Marketing, 31(2), 126-141. doi:10.1108/02652321311298735.

Jarvinen, R., \& Suomi, K. (2011). Reputation Attributes in Retailing Services: Managerial Perspective. Managing Service Quality, 21(4), 410-423. doi:10.1108/09604521111146270.

Jung, J., \& Sung, E.-Y. (2008). ConsumerBased Brand Equity; Comparisons Among Americans and South Koreans in the USA and South Koreans in Korea. Journal of Fashion Marketing and Management, 12(1), 24-35. doi:10.1108/13612020810857925.

Kalafatis, S. P., Pollard, M., East, R., \& Tsogas, M. H. (1999). Green Marketing and Ajzen's Theory of Planned Behaviour: A Cross Market Examination. Journal of Consumer Marketing, 16(5), 441-460. doi:10.1108/07363769910289550.

Kang, S., \& Hur, W. M. (2012). Investigating the Antecedents of Green Brand Equity: A Sustainable Development Perspective. Corporate Social Responsibility and Environmental Management, 19(5), 306-316. doi:10.1002/csr.281.

Keller, K. L. (1993). Conceptualizing Measuring, Managing Customer-Based Brand Equity. Journal of Marketing, 57(1), 1-22. doi:10.2307/1252054.

Keller, K. L. (2013). Strategic Brand Management (4th ed.). Tuck School of Business, Dartmouth College.

Lafferty, B. A., Goldsmith, R. E., \& Newell, S. J. (2002). The Dual Credibility Model: The Influence of Corporate and Endorser Credibility on Attitudes and Purchase Intentions. Journal of Marketing Theory and Practice, 10(3), 1-12. doi:10.1080/10696679.2002.11501916.

Lapinskiené, G., Peleckis, K., \& Radavičius, M. (2015). Economic Development and Greenhouse Gas Emissions in the European Union Countries. Journal of Business Economics and Management, 16(6), 11091123. doi:10.3846/16111699.2015.1112830.

Lee, K. (2008). Opportunities for Green Marketing: Young Consumers. Marketing Intelligence \& Planning, 26(6), 573-586. doi:10.1108/02634500810902839.

Li, Y., Lu, Y., Zhang. X. et al. (2016). Propensity of Green Consumption Behaviors in Representative Cities in China. Journal of Cleaner Production, 133, 1328-1336. doi:10.1016/j.jclepro.2016.06.012.

Malik, S. U. (2012). Customer Satisfaction, Perceived Service Quality and Mediating Role of Perceived Value. International Journal of Marketing Studies, 4(1), 68-76. doi:10.5539/ ijms.v4n1p68.

Maniatis, P. (2016). Investigating Factors Influencing Consumer Decision-Making while Choosing Green Products. Journal of Cleaner Production, 132(20), 215-228. doi:10.1016/j.jclepro.2015.02.067.

Mendleson, N., \& Polonsky, M. J. (1995). Using Strategic Alliances to Develop Credible Green Marketing. Journal of Consumer Marketing, 12(2), 4-18. doi:10.1108/07363769510084867.

Mohd Yasin, N., Nasser Noor, M., \& Mohamad, O. (2007). Does Image of Countryof-Origin Matter to Brand Equity? Journal of Product \& Brand Management, 16(1), 38-48. doi:10.1108/10610420710731142.

Mostafa, M. M. (2007). Gender Differences in Egyptian Consumers' Green Purchase Behavior: The Effects of Environmental Knowledge, Concern, and Attitude. International Journal of Consumer Studies, 31(3), 220-229. doi:10.1111/j.1470-6431.2006.00523.x.

Mourad, M., Serag, Y., \& Ahmed, E. (2012). Perception of Green Brand in an Emerging Innovative Market. European Journal of Innovation Management, 15(4), 514-537. doi:10.1108/14601061211272402.

Nadlifatin, R., Lin, S-Ch., \& Rachmaniati, Y. P., Persada, S. F., \& Razif, M. (2016). A ProEnvironmental Reasoned Action Model for Measuring Citizens' Intentions Regarding Ecolabel Product Usage. Sustainability, 8(11), 1165. doi:10.3390/su8111165.

Newell, S. J., \& Goldsmith, R. E. (2001). The Development of a Scale to Measure Perceived Corporate Credibility. Journal of Business Research, 52(3), 235-247. doi:10.1016/S01482963(99)00104-6.

Ng, P. F., Butt, M. M., Khong, K. W., \& Ong, F. S. (2014). Antecedents of Green Brand Equity: An Integrated Approach. Journal of Business Ethics, 121(2), 203-215. doi:10.1007/s10551-013-1689-z.

Oliver, J. D., \& Lee, S. H. (2010). Hybrid Car Purchase Intentions: A Cross-Cultural Analysis. Journal of Consumer Marketing, 27(2), 96-103. doi:10.1108/07363761011027204. 
Ottman, J. A., Stafford, E. R., \& Hartman, C. L. (2006). Avoiding Green Marketing Myopia. Environment, 48(5), 22-36. doi:10.3200/ENVT.48.5.22-36.

Papasolomou, I., \& Vrontis, D. (2006). Building Corporate Branding through Internal Marketing: The Case of the UK Retail Bank Industry. Journal of Product and Brand Management, 15(1), 37-47. doi:10.1108/10610420610650864.

Parasuraman, A., \& Grewal, D. (2000). The impact of Technology on the Quality-ValueLoyalty Chain: A Research Agenda. Journal of the Academy of Marketing Science, 28(1), 168174. doi:10.1177/0092070300281015.

Parasuraman, A., Zeithaml, V. A., \& Berry, L. (1988). SERVQUAL: A Multiple -Item Scale for Measuring Customer Perceptions of Service Quality. Journal of Retailing, 64, 12-37.

Paul, J., Modi, A., \& Patel, J. (2016). Predicting Green Product Consumption Using Theory of Planned Behavior and Reasoned Action. Journal of Retailing and Consumer Services, 29, 123-134. doi:10.1177/0092070300281015.

Peattie, K. (1995). Environmental marketing management. London: Pitman Publishing Corp.

Pickett-Baker, J., \& Ozaki, R. (2008). ProEnvironmental Products: Marketing Influence on Consumer Purchase Decision. Journal of Consumer Marketing, 25(5), 281-293. doi:10.1108/07363760810890516.

Polonsky, M. J., \& Rosenberger, P. J. (2001). Reevaluating Green Marketing: A Strategic Approach. Business Horizons, 44(5), 21-30. doi:10.1016/S0007-6813(01)80057-4.

Porter, M. E., \& Van der Linde, C. (1995). Toward a New Conception of the EnvironmentCompetitiveness Relationship. The Journal of Economic Perspectives, 9(4), 97-118. doi:10.1257/jep.9.4.97.

Rahman, K. M., \& Haque, M. (2011). Exploring Price Sensitivity of a Green Brand: A Consumers' Perspective. World Review of Business Research, 1(2), 84-97.

Rios, F., Martinez, T., Moreno, F., \& Soriano, P. (2006). Improving Attitudes towards Brands with Environmental Associations: An Experimental Approach. The Journal of Consumer Marketing, 23(1), 26-34. doi:10.1108/07363760610641136.

Roe, B., Teisl, M. F., Levy, A., \& Russell, M. (2001). US Consumers' Willingness to Pay for Green Electricity. Energy Policy, 29(11), 917-925. doi:10.1016/S0301-4215(01)00006-4.
Royne, M. B., Levy, M., \& Martinez, J. (2011). The Public Health Implications of Consumers' Environmental Concern and their Willingness to Pay for a Co-Friendly Product. The Journal of Consumer Affairs, 45(2), 329343. doi:10.1111/j.1745-6606.2011.01205.x.

Senthilnathan, S., \& Tharmi, U. (2012). The Relationship of Brand Equity to Purchase Intention. The IUP Journal of Marketing Management, 6(2), 7-26. doi:10.2139/ssrn.1935740.

Simionescu, M. (2013). A Profile of Romanian Highly Educated Eco-Consumers Interested in Product Recycling. A Statistical Approach. Folia Oeconomica Stetinensia, 13(2), 158-170. doi:10.2478/foli-2013-0013.

Simon, C. J., \& Sullivan, M. W. (1993). The Measurement and Determinants of Brand Equity: A Financial Approach. Marketing Science, 12(1), 28-52. doi:10.1287/ mksc.12.1.28.

Snoj, B., Pisnik Korda, A., \& Mumel, D. (2004). The Relationships among Perceived Quality, Perceived Risk and Perceived Product Value. Journal of Product \& Brand Management, 13(3), 156-167. doi:10.1108/10610420410538050.

Srinivasan, V., Park, C. S., Chang, D. R. (2005). An approach to the measurement, analysis, and prediction of brand equity and its sources. Management Science, 51(9), 14331448. doi:10.1287/mnsc. 1050.0405.

Sternthal, B., Phillips, L., \& Dholakia, E. (1978). The Persuasive Effects of Source Credibility: A Situational Analysis. Public Opinion Quarterly, 42(3), 285-314. doi:10.1086/268454.

Suki, N. M. (2017). Green Products Usage: Structural Relationships on Customer Satisfaction and Loyalty. International Journal of Sustainable Development and World Ecology, 24(1), 88-95. doi:10.1080/13504509. 2016.1169563.

Sweeney, J. C., Soutar, G. N., \& Johnson, L. W. (1999). The Role of Perceived Risk in the Quality-Value Relationship: A Study in a Retail Environment. Journal of Retailing, 75(1), 77-105. doi:10.1016/S0022-4359(99)80005-0.

Sweeney, J., \& Swait, J. (2008). The Effects of Brand Credibility on Customer Loyalty. Journal of Retailing and Consumer Services, 15(3), 179-193. doi:10.1016/j.jretconser.2007.04.001.

Wang, H.-J. (2016). Green Brand Positioning in the Online Environment. International Journal of Communication, 10, 1405-1427. 
Washburn, J. H., \& Plank, R. E. (2002). Measuring Brand Equity: An Evaluation of a Consumer Based Brand Equity Scale. Journal of Marketing Theory and Practice, 10(1), 46-62. doi:10.1080/10696679.2002.11501909.

Yoo, B., Donthu, N., \& Lee, S. (2000). An Examination of Selected Marketing Mix Elements and Brand Equity. Journal of the Academy of Marketing Science, 28(2), 195-211. doi:10.1177/0092070300282002.

Zeithaml, V. A. (1988). Consumer Perceptions of Price: A Means-End Model and Synthesis of Evidence. Journal of Marketing, 52(3), 22-39. doi:10.2307/1251446.

Zeithaml, V. A. (2000). Service quality, profitability, and the economic worth of customers: what we know and what we need to learn. Journal of the Academy of Marketing Science, 28(1), 67-85. doi:10.1177/0092070300281007.

Zhu, Q., \& Sarkis, J. (2016). Green Marketing and Consumerism as Social Change in China: Analyzing the Literature. International Journal of Production Economics, 181(SI), 289302. doi:10.1016/j.ijpe.2016.06.006.
PhD candidate, Ahmad Esmaeili, MSc. Allameh Tabataba'i University

Faculty of Accounting and Management Department of Industrial Management Ahmet.ismaeili@gmail.com

PhD candidate, Akbar Sepahvand, MSc. Allameh Tabataba'i University Faculty of Accounting and Management Department of Marketing Management a.sepahvand1991@gmail.com

Assist. Prof. Reza Rostamzadeh, Ph.D. Islamic Azad University Urmia Branch Department of Management r.rostamzadeh@iaurmia.ac.ir

Assoc. Prof. Izolda Joksiene, Ph.D. Vilnius Gediminas Technical University Faculty of Business Management Department of Economics and Management of Enterprises izolda.joksiene@vgtu.It

Prof. Jurgita Antucheviciene, Ph.D. Vilnius Gediminas Technical University Faculty of Civil Engineering Department of Construction Management and Real Estate jurgita.antucheviciene@vgtu.It 


\title{
Abstract
}

\section{EFFECT OF INTEGRATION OF GREEN CONSTRUCTS AND TRADITIONAL CONSTRUCTS OF BRAND ON GREEN PURCHASE INTENTION OF CUSTOMERS}

\author{
Ahmad Esmaeili, Akbar Sepahvand, Reza Rostamzadeh, Izolda Joksiene, \\ Jurgita Antucheviciene
}

The urgent concerns for environmental issues and growing demand for green products have made companies pay much more attention to green marketing. Although, many companies invest in green marketing, but not all of them gain as much as they invest. Most of failures of investments in green marketing are rooted in the fact that customers doubt both the real green performance of these products and the real intention of companies regarding green products. This research, being quantitative in nature, attempts to investigate the impact of traditional branding constructs (perceived quality of the brand, credibility of the brand) and green branding constructs (perceived value of a green brand, the green brand image, and brand equity) on the green purchase intention of customers. The hypotheses have been developed in the form of a conceptual model to investigate the relationship of these constructs. The research focuses on consumers of certain liquid washing detergent products. All the data were collected using questionnaires and the analysis of the data was conducted utilizing LISREL 8 and SPSS 16. The results indicate that perceived brand quality has a positive impact on the perceived value of a green brand, brand credibility, and brand image. In addition, green brand value and green brand image have a positive impact on brand equity. This research can serve as validation of the constructs to fill the gap in the investigation of green brand dimensions. Further analysis shows that green brand equity has a meaningful impact on the green purchase intention of the customers, however the impact of brand credibility on brand equity has not been proved.

Key Words: Green brand, traditional branding constructs, green branding constructs, brand equity, green purchase intention.

JEL Classification: M31, Q56.

DOI: 10.15240/tul/001/2017-3-015 